\title{
KOBIETA I JEJ ROLA W HISTORII ZBAWIENIA WEDLUG KLEMENSA ALEKSANDRYJSKIEGO ${ }^{1}$
}

O Klemensie Aleksandryjskim i jego stosunku do kobiet krążą opinie, które sprawiają, że postrzega się go jako mizogina, albo przynajmniej kogoś, kto o kobietach wyrażał się - delikatnie mówiąc - niepochlebnie. Czytelnik znanej Encyklopedii ,,drugiej płci”, która w swym trzecim wydania nosi nawet podtytuł Wszystko o kobietach pod redakcją najbardziej chyba znanego polskiego leksykografa Władysława Kopalińskiego, może przeczytać tam taką oto pikantną opinię o kobietach przypisywaną Klemensowi: „Wstyd kobiet mieści się w ich koszuli i dopiero, gdy się uda nam ją zdjąć, on znika nie pozostawiając nawet cienia"2. Próżno by jednak szukać tego zdania w dziełach Klemensa Aleksandryjskiego. Sam zresztą Kopaliński nie podaje odnośnika do jego dzieł. Podaje natomiast odnośnik inny: „Cytat za: G.G. Casanova, Pamiętniki 6, 10”. Nie trzeba tu przedstawiać postaci tego bodaj najbardziej znanego awanturnika i uwodziciela z XVIII wieku. Można się tylko zastanawiać, skąd Casanova znał Klemensa Aleksandryjskiego i jemu przypisywał tę opinię. Otóż, rzadko kto wie, że rodzina G.G. Casanovy chcąc go utemperować, ulokowała go w seminarium duchownym, gdzie wprawdzie nie zagrzał długo miejsca, ale jednak przez jakiś czas studiował teologię i tam zapewne trafił na dzieła Klemensa, które w tym przynajmniej aspekcie osobliwie sobie przyswoił. Otóż, jeśli wytrwale poszukać miejsca, z którego Casanova mógł zaczerpnąc tę opinię o kobietach, to w III księdze Wychowawcy znajdziemy taki oto fragment:

„Starożytni atleci, wstydząc się męskiej nagości, by zachować przyzwoitość, występowali na zawodach z przepaską, podczas gdy pragnące być pięknymi kobiety, porzucając wraz z chitonem swój wstyd, udowadniają swą złą opinię"”.

* Dr Stanisław Łucarz SJ - adiunkt w Katedrze Historii Filozofii na Wydziale Filozoficznym Akademii Ignatianum w Krakowie; e-mail: stanislaw.lucarz@ignatianum.edu.pl.

${ }^{1} \mathrm{~W}$ artykule tym podejmowana jest podobna tematyka, co w mojej pracy: S. Łucarz, Grób czy światynia. Problematyka cielesności w antropologii Klemensa Aleksandryjskiego, Kraków 2007, WAM. Jest to jednak tematyka przepracowana i uzupełniona o aspekt soteriologiczny.

${ }^{2}$ W. Kopaliński, Encyklopedia „,drugiej ptci”: Wszystko o kobietach, Warszawa 1995, Oficyna Wydawnicza RYTM, 573.

${ }^{3}$ Clemens Alexandrinus, Paedagogus III 33, 1, PG 8, 601B-C, thum. M. Szarmach, Klemens 
Klemens krytykuje tu nago kạpiące się kobiety, zalecając im szczególną wstydliwość. Trzeba było więc iście awanturniczej na miarę Casanovy interpretacji Klemensa, aby dojść do takiej opinii.

Także wśród znanych teologów zdarzają się tacy, którzy są rzecznikami poglądu o mizoginii Klemensa. W znanej książce Kobieta i zbawienie świata Paul Evdokimov umieszcza Klemensa pośród tych postaci ze starożytności chrześcijańskiej, które wyróżniały się najbardziej negatywnymi opiniami o kobietach i cytuje takie oto jego zdanie: „każdą kobietę powinna napawać obrzydzeniem sama myśl, że jest kobieta" ". Również w tym przypadku mamy do czynienia z niewłaściwymi zarówno tłumaczeniem i jak interpretacją myśli Klemensa. Klemens bowiem jest przekonany, że wszystko, co Bóg stworzył, jest dobre, i nie ulega dla niego najmniejszej wątpliwości, że tak kobieta jak i mężczyzna jako stworzenia Boże, są dobrzy i że nie ma tu jakiegokolwiek powodu od obrzydzenia. Poza tym samo słowo obrzydzenie jest tu nie na miejs-

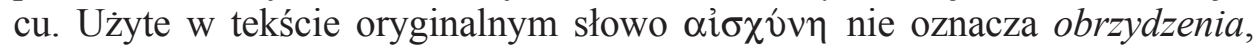
a wstyd, zawstydzenie, poczucie wstydu... Marna by to była jednak pociecha, gdyby się okazało, że kobieta ma wstydzić się swojej kobiecości. Byłaby to tylko zmiana stopnia negatywnego stosunku do samej siebie. Otóż, jak się okazuje ani thumacze, ani sam Evdokimov nie zagłębili się w filozofię i teologię płci u Klemensa. Tę uwagę tylko w części można odnieść do polskiego tłumacza Mariana Szarmacha, który cytowane przez P. Evdokimowa zdanie oddaje w następujący sposób: ,a już zwłaszcza kobieta, jeśli ma przyrodzone poczucie wstydu i sumienie"'5. Nie jest to thumaczenie zbyt wierne, ale unika pułapki, w którą wpadł P. Evdokimov. Klemens w swej filozofii płci uważa, że zarówno mężczyzna jak i kobieta mają takie same dusze. To, co ich różni, to ciała i z tej różnej cielesności wynikają też różne słabości i związane z nimi namiętności. I tak jeśli dla mężczyzn typową namiętnością i zarazem pokusąjest $\theta v \mu$ ó czyli gniew, a nawet napady gniewu, których skutkiem jest agresywność; to dla kobiety taką namiętnością jest દ̇ $\pi \imath \theta v \mu i ́ \alpha$ czyli pożadliwość płciowa prowadząca do bezwstydu. Dlatego to antidotum na te namiętności w przypadku mężczyzny jest $\mu \varepsilon \tau$ óvoro czyli zmiana usposobienia w postaci skruchy, natomiast dla

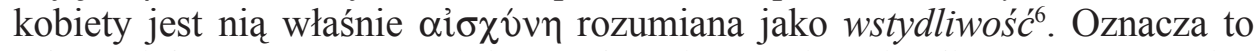
tyle, że jak mężczyzna powinien poskramiać swoją gniewliwość, czy mówiąc nowocześniej agresywność, poprzez skruchę, tak kobieta powinna starać się

Aleksandryjski, Wychowawca, Torun 2012, Wydawnictwo Naukowe Uniwersytetu Mikołaja Kopernika, 185.

${ }^{4}$ P. Evdokimov, Kobieta i zbawienie świata, tłum. E. Wolicka, Poznań 1991, Wydawnictwo Polskiej Prowincji Dominikanów „W Drodze”, 187. Por. Clemens Alexandrinus, Paedagogus II 33,

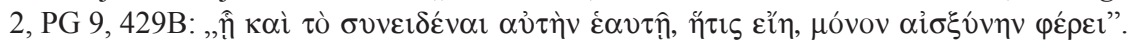

${ }^{5}$ Clemens Alexandrinus, Paedagogus II 33, 2, PG 9, 429B, thum. Szarmach, s. 102.

${ }^{6}$ Por. tenże, Stromata III 93, 1, PG 8, 1193A, tłum. J. Niemirska-Pliszczyńska: Klemens Aleksandryjski, Kobierce zapisków filozoficznych dotyczacych prawdziwej wiedzy, I, Warszawa 1994, Instytut Wydawniczy Pax, Akademia Teologii Katolickiej, 191. 
o wstydliwość. Zresztą tę cnotę wstydliwości u znanych w starożytności kobiet Klemens podkreśla i wychwala, jak tylko może ${ }^{7}$.

1. Zasadnicza równość mężczyzny i kobiety. Bardzo ważne jest tu słowo „zasadnicza”, bo też ta równość dotyczy natury i zasady człowieczeństwa, którą dla Klemensa jako platonika jest dusza. Jak już wcześniej wspomniałem, różnice i - jak się okaże - ostatecznie i nierówność, dotyczą ciała i z niego wynikają. Oddajmy jednak głos samemu Klemensowi. Otóż pisze on na ten temat, co następuje:

„Przecież w ramach gatunku ludzkiego nie jest oczywiste, żeby kobieta posiadała inną naturę, a mężczyzna inną! Ale chyba tę samą, a jeśli tak, to również tę samą cnotę. Jeśli więc uważa się, że męską cnotą jest wstrzemięźliwość oraz sprawiedliwość i inne cnoty im towarzyszące, to jedynie przystoi mężczyźnie być cnotliwym, kobieta zaś ma być rozwiązła i niesprawiedliwa? Doprawdy, aż wstyd to mówić! Nic podobnego! Zabiegać o wstrzemięźliwość, o sprawiedliwość i wszelką inną cnotę powinni jednakowo kobieta i mężczyzna, wolny i niewolnik, jeśli jedna i ta sama cnota przysługuje tej samej naturze"s.

Jeszcze dobitniej wyraża tę ideę w innym miejscu:

„Taka sama jest cnota dla mężczyzn i kobiet, mają przecież tego samego jedynego Boga, tego samego wychowawcę, jeden i ten sam Kościół, tę samą moralność, to samo poczucie wstydu, wspólne pożywienie, razem łączy ich małżeństwo, oddychanie, widzenie, słyszenie, poznawanie, posłuszeństwo i zdolność do miłości: wszystko mają wspólne. Dla tych więc, dla których życie jest wspólne i łaska jest wspólna, wspólne i zbawienie, i cnota, i sposób życia. [...] Mężczyźni i kobiety mają też to samo wspólne imię: człowiek"”.

$\mathrm{Z}$ tego powodu jest dla niego naturalną konsekwencją że kobiety należy kształcić w cnocie tak samo jak i mężczyzn:

„Jak bowiem dla mężczyzny piękną jest rzeczą ponieść śmierć za dzielność

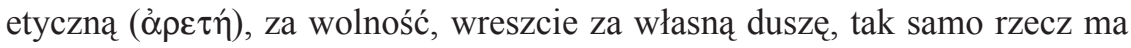
się z kobietą. Nie jest to bowiem wyłączną własnością natury mężczyzn, lecz natury dobrych ludzi” ${ }^{\prime 10}$.

I parę wersetów dalej:

„W tej doskonałości uzyskać udział może na równi mężczyzna i kobieta”"11.

\footnotetext{
${ }^{7}$ Por. tamże IV 120, 1 PG 8, 1329A-B, thum. Niemirska-Pliszczyńska, I, s. 363.

${ }^{8}$ Tamże IV 59, 1-4 PG 8, 1271B-C, tłum. Niemirska-Pliszczyńska, I, s. 330.

${ }^{9}$ Clemens Alexandrinus, Paedagogus I 10, 1 - 11, 1, tłum. Szarmach, s. 25.

${ }^{10}$ Tenże, Stromata IV 67, 4, PG 8, 12787D - 1280A, thum. Niemirska-Pliszczyńska, I, s. 334.

${ }^{11}$ Tamże IV 118, 1 PG 8, 1328A, thum. Niemirska-Pliszczyńska, I, s. 362.
} 
Co więcej uważa, że:

„Kobiety powinny mieć także prawo do uprawiania filozofii na równi z mężczyznami"'2.

Wymienia cały zastęp wybitnych kobiet, które odznaczyły się najwyższymi cnotami, podkreślając szczególnie te, które odznaczyły się na polu filozofii. Zaczyna, jak przystało na chrześcijanina od postaci ze Starego Testamentu i wylicza Sarę, Judytę i Esterę, a potem postaci z literatury i historii helleńskiej: Nauzykaę, Lizydike, Filoterę [którą nazywa lwicą attycka], Telezyllię, Atalantę, Teano, Aspazję z Miletu i wiele innych ${ }^{13}$. Odnosząc się zaś do chrześcijan pisze:

„Pełen jest cały Kościół takich ludzi, którzy przez całe życie ćwiczą się w gotowości przyjęcia życiodajnej śmierci wiodącej ich do Chrystusa, i to zarówno obyczajnych mężczyzn jak kobiet. Wolno jest bowiem każdemu żyjącemu w naszej wspólnocie dążyć do mądrości, nawet bez wykształcenia, czy to będąc barbarzyńcą czy Hellenem, czy niewolnikiem, czy wolnym, czy starcem, czy dzieckiem, czy kobietą. [...] Wszak jest między nami uzgodnione, że w ramach tego samego gatunku, ci którzy mają tę samą naturę, uzyskują tę samą cnotę"14.

Jest rzeczą charakterystyczną, że wśród tych wielkich postaci kobiecych nie wymienia z imienia Maryi, matki Jezusa. Nie oznacza to jednak, że nie był świadomy jej cnót. Wynika to raczej z tego, że wiąże ją ściśle z Jezusem Logosem, i tak jak nie stawia Jezusa $w$ jednym szeregu $\mathrm{z}$ innymi ludźmi, tak też czyni i z Jego Matką. Owszem, będzie o niej mówił, ale w zupełnie innym kontekście, ściśle wiążąc Ją z Jezusem.

2. Różnice między mężczyzną i kobietą. Jak już wspomniałem, różnice te nie dotyczą duszy, lecz ciała, a oto słowa samego Klemensa, które to uwydatniają:

„Nie utrzymujemy bynajmniej, że ta sama jest natura samicy, co samca - jeśli chodzi o jej funkcję jako samicy. Musi przecież między obydwoma rodzajami istnieć różnica, na podstawie której można zakwalifikować je płciowo odrębnie. Kobiecie przystoi - naszym zdaniem - nosić płód w łonie i rodzić, co jest jej funkcją jako samicy, a nie jako człowieka. [...] W jakim zakresie jest ko-

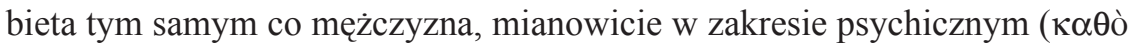
$\psi v \chi \eta ́)$, w tymże osiąga tę samą możliwość dzielności moralnej (⿳亠丷厂 W jakim zaś jest czymś różnym, a mianowicie w zakresie odrębności ciele-

\footnotetext{
${ }^{12}$ Tamże IV 62, 3 PG 8, 1273B - 1276A, tłum. Niemirska-Pliszczyńska, I, s. 331.

${ }^{13}$ Por. tamże IV 118, 1 - 124, 1, PG 9, 1328A - 1336A, tłum. Niemirska-Pliszczyńska, I, s. 362-366.

${ }^{14}$ Tamże IV 58, 2-4, PG 8, 1272A, thum. Niemirska-Pliszczyńska, I, s. 330.
} 


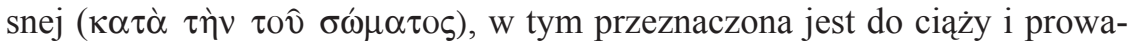
dzenia domu"15.

Ta odmienność na poziomie ciała nie jest tylko innością nienaruszającą w niczym równości między mężczyzna a kobietą. Ciało kobiety jest słabsze fizycznie, i - jak zobaczymy - będzie to miało poważne konsekwencje i na innych polach. Klemens jakby w pierwszym odruchu stara się pokazać, że ta fizyczna słabość nie oznacza, że kobiety są gorsze. Pisze bowiem:

„Dochodzą do mnie wieści, że kobiety sarmackie biorą udział w wojnie nie gorzej od mężczyzn, a znowu kobiety z plemienia Saków pozorując ucieczkę strzelają z łuku do tyłu - na równi z mężczyznami. Wiem, że także kobiety mieszkające niedaleko Iberii pełnią prace i trudy jak mężczyźni: będąc w zaawansowanej ciąży nie przerywają bynajmniej normalnych obowiązkowych czynności"'16.

Po takich stwierdzeniach spada na czytelnika niemalże jak grom z jasnego nieba zdanie Klemensa, że - choć kobiety i mężczyźni na poziomie duszy są równi, to jednak ci drudzy, czyli mężczyźni

„wyprzedzają kobiety pod każdym względem, chyba, że ulegną zniewieściałości" ${ }^{17}$.

Skąd taki wniosek? Jak już wspomniałem, przyczyną jest tu nie dusza, lecz ciało. Ciało mężczyzny jest zdaniem Klemensa nie tylko silniejsze fizycznie, ale i pełniejsze czyli doskonalsze. Chodzi tu przede wszystkim o to, że według przekonania, które panowało od starożytności aż po wiek XVIII, a nawet początek XIX, to mężczyzna przekazuje życie, a kobieta jest tylko rolą przyjmującą nasienie i dającą temuż nasieniu możliwość wzrostu. Klemens pisze wprost:

„Jemu [mężczyźnie] przypisane jest działanie ( $\tau$ ò $\delta \rho \hat{\alpha} v)$, jej [kobiecie] bier-

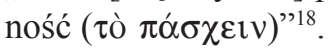

A dla starożytnych było rzeczą oczywistą, że to aktywność ma pierwszeństwo nad biernością. Ta bierność, a przynajmniej większa bierność, ciała kobiety ma swe dalsze konsekwencje. $Z$ powodu tej bierności ciało kobiety bardziej ulega namiętnościom niż ciało mężczyzny, wszak istotą namiętności ( $\pi \alpha ́$ óos) jest właśnie bierność ( $\tau o ̀ ~ \pi \alpha ́ \alpha \chi \varepsilon \imath v$ ). To właśnie przez ciało namiętności dostają się do duszy. Owszem, w ten sam sposób dostają się one też do duszy mężczyzny, ale z tej racji, iż ciało mężczyzny jest aktywniejsze i mniej poddane bierności, stąd też i napór namiętności na duszę jest w przypadku mężczyzny mniejszy niż w przypadku kobiety. Choć więc dusze mężczyzn i kobiet są równe, to dusza kobiety jest w trudniejszym położeniu. Tak zatem widzimy

\footnotetext{
${ }^{15}$ Tamże IV 59, 5 - 60, 1, PG 8, 1272B-C, thum. Niemirska-Pliszczyńska, I, s. 330.

${ }^{16}$ Tamże IV 62, 1-2, PG 8, 1273B - 1276A, thum. Niemirska-Pliszczyńska, I, s. 331.

${ }^{17}$ Tamże IV 63, 1, PG 8, 1276A, thum. Niemirska-Pliszczyńska, I, s. 332.

${ }^{18}$ Tenże, Paedagogus III 19, 1-2, PG 8, 581B, thum. Szarmach, s. 176.
} 
jasno, jak to się dzieje, że mężczyźni „wyprzedzają kobiety po każdym względem”, także gdy chodzi o duszę. Z tego przekonania, iż przez słabość ciała i dusza kobiety bardziej narażona jest na namiętności, Klemens wyprowadza następujący wniosek:

„Dlatego należy stosownie ograniczyć wolność kobiet i nałożyć im dyscyplinę wstydliwości, aby przez próżność nie odeszły od prawdy"19.

Pojawia się znów zatem wstydliwość jako cnota przynależna kobiecie, o czym mowa była wcześniej, ale tym razem ma już ona swoje filozoficzne uzasadnienie. Wspomniana potrzeba ograniczenia wolności kobiet posłuży Klemensowi do wyjaśnienia zalecenia św. Pawła, iż żona ma być poddana mężowi, bo mąż jest głową żony. Klemens idzie jeszcze dalej niż Apostoł i uważa, że to nie tylko mąż jest głową żony, lecz mężczyzna w ogóle jest głową kobiety ${ }^{20}$. Sięga też po porównanie zaczerpnięte z filozofii stoickiej i pisze, że pełni on w sto-

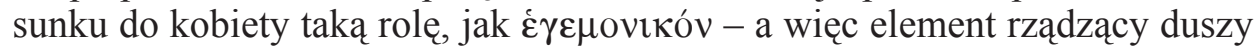
w stosunku do reszty w człowieku. Nie waha się w końcu nawet napisać, że mężczyzna jest panem (кúpıoৎ) kobiety ${ }^{21}$. Jak więc widzimy z tych wcześniejszych zapewnień o równości zostało raczej niewiele. Od tych zasad jest jednak pewien wielce znaczący wyjątek, kiedy kobieta przynajmniej w pewniej mierze jest wyłączona spod panowania mężczyzny. Jest tak zaś wtedy, kiedy ona jest chrześcijanką, a jej mąż poganinem, który nie chce się nawrócić na chrześcijaństwo. Klemens tak pisze o tej sytuacji:

„Powinna więc rozumna żona najpierw przekonywać męża, aby wspólnie z nią podejmował wysiłki mające na celu uzyskanie eudajmonii. Jeśliby zaś

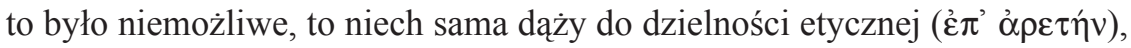
będąc jednocześnie we wszystkim posłuszna mężowi, aby niczego nie uczyniła wbrew jego woli, z wyjątkiem tego, co uważa się za decydujące dla cnoty i zbawienia"22.

Tę myśl Klemens rozwija gdzie indziej:

,jeśli on [mąż] nie chce dać jej słowom posłuchu, to wtedy musi ona spróbować, na ile to jest możliwe w ramach ludzkiej natury, sama pokierować swoim życiem w sposób bezgrzeszny, trwając przy Logosie, zarówno gdy wypadnie jej umrzeć, jak i żyć dłużej. W każdym razie winna uważać Boga za swą podporę i wspólnika w takim działaniu, za swego prawdziwego obrońcę i wybawcę w chwili obecnej czy na przyszłość, gdyż wybrała Go na wodza i przewodnika wszelkiej swej działalności. Za właściwe zadanie swego życia

${ }^{19}$ Tamże III 58, 1, PG 8, 632C, tłum własne; przekład własny stosuję w tych miejscach, w których przekład polski na tyle odbiega od oryginału, że wyraża inną myśl niż ta, którą - moim zdaniem - autor zawarł w tekście oryginalnym.

${ }^{20}$ Tenże, Stromata IV 63, 5, PG 8, 1276B, tłum. własne; por. 1Kor 11, 3. 7.

${ }^{21}$ Por. tamże IV 64, 1, PG 8, 1276B, por. Ef 5, 22-24.

${ }^{22}$ Tamże IV 123, 2, PG 8, 1333B, tłum. własne. 
uzna umiarkowanie i sprawiedliwość, a za jego cel bycie ukochaną przez Boga"23.

Jest to wniosek spójny z całą antropologią Klemensa, w której celem człowieka jest ỏjó $\theta \varepsilon \imath \alpha$ czyli totalne wyzbycie się namiętności, a w ostatecznej

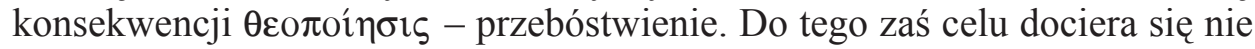
inaczej jak tylko poprzez Chrystusa - Boski Logos, to kobieta - przez swe słabsze ciało bardziej narażona na namiętności - trwając przy Logosie jest w znacznie lepsze sytuacji niż mężczyzna pozbawiony zbawczej pomocy Logosu. Ostatecznie bowiem naszemu autorowi nie chodzi przecież o wyższość czy niższość kobiety względem mężczyzny, lecz o zbawienie tak jednych jak i drugich i o to, kto komu skuteczniej w drodze do tegoż zbawienia będzie pomagał. W sytuacji, kiedy mężczyzna i kobieta są chrześcijanami, jest dla niego rzeczą oczywistą, iż tą osobą będzie mężczyzna. W przypadku jednak, kiedy ona jest chrześcijanką, a on poganinem, to kobieta właśnie prowadzi mężczyznę do Logosu, będąc mu jednocześnie posłuszna, ale „,z wyjątkiem tego, co uważa się za decydujące dla cnoty i zbawienia”.

3. Perspektywa eschatologiczna. Ostatecznie cel swój człowiek - zarówno kobieta jak i mężczyzna - osiąga w eschatologii, gdyż jak to czytamy w I księdze Wychowawcy:

„Pismo mówi: «Dzieci tego świata żenią się i za mąż wychodzą». W tym życiu kobieta różni się od mężczyzny, w przyszłym zaś nie. Tam za życie wspólne i święte zostały przygotowane nagrody nie dla mężczyzn i kobiet, ale dla człowieka wyzwolonego od pożądliwości. To pożądliwość dzieli go na dwie różne istoty. Istnieje przeto wspólne określenie dla mężczyzn i kobiet: człowiek" ${ }^{24}$.

Stwierdzenie, że pożądliwość dzieli człowieka na dwie różne istoty w znaczeniu płci, jest skrótem myślowym. W istocie to ciało czy raczej różnice w cielesności dzielą człowieka na dwie płci. Jednakże to ciało jest źródłem i bramą dla namiętności, dlatego też tutaj Klemens utożsamia ciało z pożądliwościami. Jednakże po zmartwychwstaniu także ciało zostanie przebóstwione i przestanie być bramą namiętności, a zatem zniknie ta różnica rodząca pożądliwość i podział.

Klemens potwierdza to w innym, bardzo ciekawym i zarazem kontrowersyjnym fragmencie, gdzie pisze:

„przecież będzie [żona] istotnie jego [męża] siostrą po wyzbyciu się ciała

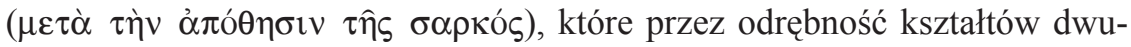
płciowych oddala i ogranicza znajomość spraw ducha. Wszak dusze są same przez się sobie równe, bez znamienia płci; nie będzie mężczyzn, ani kobiet,

\footnotetext{
${ }^{23}$ Tamże IV 127, 2, PG 8, 1337B-C, tłum. własne.

${ }^{24}$ Tenże, Paedagogus I 10, 3, PG 8, 260D - 261A, tłum. Szarmach, s. 25.
} 
gdy już żenić się nie będą ani wychodzić za mąż. I kobieta w równym stopniu przekształci się w mężczyznę, straciwszy znamię kobiecości i stawszy się zarazem męska i kobieca"25.

Zwłaszcza ostatnie zdanie tego fragmentu zrodziło wiele kontrowersji. Polski przekład jest w tym przypadku po prostu błędny. Zarówno oryginał jak i dostępne mi przekłady z łacińskim włącznie, stwierdzają, że „kobieta przekształci się w mężczyznę straciwszy znamię kobiecości i stanie się męska i doskona-

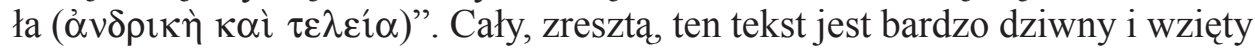
dosłownie wręcz nielogiczny. No bo jak to? Mężczyzna i kobieta wyzbędą się ciała, które decyduje o ich płciowości, nie będzie już mężczyzn, ani kobiet, a mimo to kobieta przekształci się w mężczyznę, straci znamię kobiecości i stanie się męska i doskonała. Jaki w tym sens? Po pierwsze Klemens nie używa tu słowa $\sigma \hat{\omega} \mu \alpha$, które oznacza ciało w ogóle, lecz słowa $\sigma \alpha ́ \rho \xi$, które w znaczeniu Pawłowym oznacza ciało upadłe. Owo pozbycie się ciała - $\alpha$ đó $\theta \eta$ rı

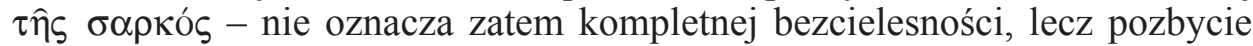
się tych jej znamion, które dzielą ludzi. Czy chodzi o fizyczne pozbycie się ich? Na podstawie tekstu Klemensa trudno to rozstrzygnąć, ale wydaje się, że raczej nie, gdyż to nie fizyczność jest problemem. Chrystus przyjął na siebie ludzką fizyczność wraz z fizycznymi znamionami płci, a mimo to był doskonale $\dot{\alpha} \pi \alpha \theta \eta \dot{\varsigma}$ - czyli wolny od namiętności, był - jak pisze św. Paweł - ỏvì $\tau \varepsilon ́ \lambda \varepsilon \iota_{0}$ - czyli mężczyznq doskonałym ${ }^{26}$. To pojęcie mężczyzny czy męża doskonałego odgrywa tu zresztą bardzo ważną rolę. Klemens bowiem operuje po mistrzowsku alegorią. Fragment ten staje się w pełni zrozumiały wtedy właśnie, jeśli sięgniemy do alegorycznego znaczenia męskości i kobiecości w teologii aleksandryjskiej. Otóż, męskość oznacza doskonałość i pełnię, a kobiecość niedoskonałość i brak pełni. Chodzi o to, że w eschatonie zarówno mężczyzna jak i kobieta osiaggną pełnię i doskonałość - na wzór mężczyzny

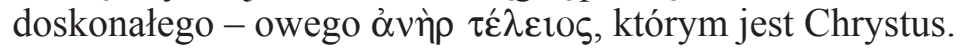

4. Kobieta a zbawienie. Klemens nie zajmuje się tym tematem nigdzie w sposób wyraźny. Nie ulega wątpliwości, że widzi kobietę zawsze w związku $\mathrm{z}$ mężczyzną. Jedynie w perspektywie eschatologicznej, która już tu na ziemi wnika w życie człowieka przez interwencję Boga w Jezusie Chrystusie, związek ten traci swą siłę. Trzeba pamiętać, że Klemens Aleksandryjski był jednym z niewielu, a może jedynym z wielkich starożytnych pisarzy kościelnych, którzy nie byli zwolennikami celibatu. Tak więc normalną drogą zbawienia było dla niego małżeństwo. Mężczyznę i kobietę na samym początku stwarza Bóg. Wspólnie wchodzą w grzech pierworodny, za który oboje ponoszą

${ }^{25}$ Tenże, Stromata VI 100, 3, PG 9, 321A-B, tłum. J. Niemirska-Pliszczyńska, II, Warszawa 1994, 171-172.

${ }^{26}$ Ef 4, 12-13, por. The Greek New Testament, ed. K. Aland - M. Black - C.M. Martini - B.M. Metzger - A. Wikgren, New York - London - Edinburgh - Amsterdam - Stuttgart 1975², United Bible Societies, 672. 
odpowiedzialność. Zdaniem Klemensa zwiodła ich pierwsza i podstawowa namiętność - przyjemność, której symbolem jest pełzający na brzuchu wąż ${ }^{27}$. Klemens przypuszcza, że materialnie grzechem tym było współżycie - a przynajmniej pożądliwe patrzenie na siebie - pierwszych rodziców przed czasem ustalonym przez Boga na ich obcowanie cielesne ${ }^{28}$. W ten sposób człowiek wpadł w niewolę namiętności, z której sam nie może siebie wyzwolić. Sytuację człowieka po grzechu Klemens przedstawia w postaci poetyckiego obrazu pisklęcia, które wypadło z gniazda i nie umiejąc jeszcze fruwać nie może tam powrócić. Na dole zaś czyha nań wąż i już rozwiera swoją paszczę, by je pożreć. W tym momencie interweniuje Bóg jako dobry Ojciec i przenosi je $\mathrm{z}$ powrotem do gniazda ${ }^{29}$. Czyni to zaś poprzez wcielony Logos. I tu pojawia się Maryja, jako matka wcielonego Logosu. Klemens nie zna jeszcze tak charakterystycznego dla wielu Ojców przeciwstawienia Ewy i Maryi - tej pierwszej jako rodzicielki umarłych czy rodzącej na śmierć i tej drugiej jako rodzicielki życia i rodzącej do życia. Tym niemniej Maryja jest ważną postacią w jego soteriologii. To właśnie w jej życie eschatologia w sensie niezależności od mężczyzny wnika z całą mocą, szczególnie w dziewiczym poczęciu Jezusa. Klemens Maryję nazywa jednym z ostatnich proroków Starego Testamentu ${ }^{30}$, a dla niego prorocy, to głos Logosu przed narodzeniem wcielonego Logosu. Maryja jest niewątpliwie takim głosem, choćby przez swoje „fiat” i „Magnificat". Tematu tego jednak szerzej nie rozwija.

5. Maryja i jej rola $w$ historii zbawienia. Maryja jest dla Klemensa

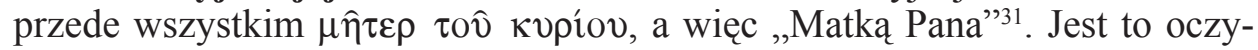
wiście tytuł, który nie on sam Jej nadaje. Przeciwnie, nawiązuje tu do całej tradycji chrześcijańskiej, mającej swe początki już w Biblii (por. Łk 1, 43). Z kolei w pierwszej księdze Wychowawcy Klemens nazwie Jezusa $\pi \alpha \rho \theta \dot{v} v o v$

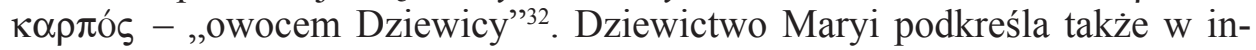
nym miejscu, gdzie krytykuje filozofów pogańskich i gnostyków uważających same narodziny w ciele za zło. Pisze tam:

„Jeśli same narodziny są czymś złym, to powinni też bluźniercy uznać, że Pan uczestnicząc w narodzinach uwikłał się w zło oraz że Najświętsza Dziewica, która Pana urodziła, też uwikłała się w zło"33.

Tu polska tłumaczka dała się porwać polskiej pobożności i zupełnie bezpodstawnie wstawiła przymiotnik „najświętsza”, którego nie ma w oryginale.

${ }^{27}$ Por. Clemens Alexandrinus, Protrepticus 111, 1, PG 8, 228C, thum. J. Sołowianiuk: Klemens Aleksandryjski, Zachęta Greków, w: Apologie, PSP 44, Warszawa 1988, ATK, 194.

${ }^{28}$ Por. tenże, Stromata III 94, 3, PG 8, 1193C - 1196A, por. Mt 5, 28.

${ }^{29}$ Tenże, Protrepticus 91, 3, PG 8, 204B-C, PSP 44, 183.

${ }^{30}$ Por. tenże, Stromata I 136, 1, PG 8, 872A, thum. Niemirska-Pliszczyńska, I, s. 94.

${ }^{31}$ Tamże I 147, 5 PG 8, 889B, tłum. Niemirska-Pliszczyńska, I, s. 103.

${ }^{32}$ Tenże, Paedagogus I 41, 3 PG 8, 300B, thum. Szarmach, s. 43.

${ }^{33}$ Por. tenże, Stromata III 102, 1 PG 8, 1205A, thum. Niemirska-Pliszczyńska, I, s. 289. 
Gdyby był, wskazywałby być może na jakiś rodzaj kultu, Klemens jednak pozostaje przy samej dziewiczości Maryi, nie sugerując tu ani słowem nic więcej. Gdzie indziej rozprawiając się z doketami i streszczając ich poglądy również zaznacza, że Jezus był noszony w łonie Dziewicy ${ }^{34}$. Najwięcej miejsca jednak poświęci dziewiczemu macierzyństwu Maryi w siódmej księdze Kobierców. Co więcej, bodaj jako pierwszy w historii teologii chrześcijańskiej sformułuje tezę, iż nie tylko poczęła jako dziewica, ale pozostała dziewicą także in partu i post partum. Czytamy tam:

„Podobno szerokim masom, i to do dnia dzisiejszego, wydaje się, że Maryja była położnicą, dlatego że urodziła dziecko, choć położnicą nie była, ponieważ już po urodzeniu dzieciątka, gdy była oglądana przez położna, jak powiadają niektórzy, znaleziono ją dziewicą" ${ }^{35}$.

Uzasadniając dziewictwo Maryi in partu cytuje tekst apokryficzny, którego pochodzenia nie jesteśmy $\mathrm{w}$ stanie zidentyfikować, a brzmi on:

„«Ona urodziła i nie urodziła zarazem» - mówi Pismo - ponieważ poczęła

z samej siebie, nie z kontaktu z mężczyzną"36.

Jak widzimy, Klemens podkreśla tu bardzo mocno dziewicze poczęcie, „nie z kontaktu z mężczyzną”. W przypadku Maryi realizuje się par excellence to, co Klemens pisał o kobiecie -chrześcijance, której mąż jest poganinem. To wybranie Maryi przez Boga stawia ją ponad mężczyznę, którego była żoną, chociaż jej mąż - Józef - nie był przecież poganinem. Jednakże Boży wybór i wynikająca z niego misja Maryi sprawia, że Jej panem jest Bóg. Sama zresztą nazywa siebie w momencie zwiastowania $\delta$ ov́ $\lambda \eta$ Kvpíov - „Służebnicą Pańską" (Łk 1, 38) ${ }^{37}$. Tak zdecydowane opowiedzenie się Klemensa za dziewiczym macierzyństwem Maryi ante partum, in partu et post partum wynika nie tyle z maryjnej pobożności Klemensa. Nie wiadomo zresztą czy taką się odznaczał, bo też jego „mariologia” nie ma charakteru niezależnego. Jest integralną częścią jego soteriologii. Co więcej, można by wręcz powiedzieć, że jest jej podporządkowana. Można by nawet poważyć się na stwierdzenie, że została stworzona na jej potrzeby.

Otóż, jak już wspomnieliśmy nieco wcześniej, celem człowieka jest jego przebóstwienie, do którego dochodzi on poprzez wyzbycie się namiętności - $\alpha \pi \alpha ́ \theta \varepsilon \imath \alpha$. Do tego celu prowadzi człowieka Boski Logos, co więcej, bez tegoż Logosu jako lekarza, nauczyciela, zbawiciela i wzoru osiągnięcie tego

${ }^{34}$ Por. tamże VI 127, 1 PG 9, 349C, thum. Niemirska-Pliszczyńska, II, s. 189.

${ }^{35}$ Tamże VII 93, 7 PG 9, 529B, thum. Niemirska-Pliszczyńska, II, s. 294.

${ }^{36}$ Tamże VII 94, 2 PG 9, 532A, thum. Niemirska-Pliszczyńska, II, s. 295. Polska thumaczka podaje w tym przypisie odnośniki do dzieł Tertuliana (De carne Christi 23), Epifaniusza (Haereses 30, 30) i Grzegorza z Nyssy (Adversus Iudaeos 303). Nie rozwiązuje to jednak problemu, bo Klemens powołuje się tu nie na teologów, z których dzieł i tak nie mógł korzystać, ale na tekst Pisma Świętego, który miał dla niego autorytet.

${ }^{37}$ Por. The Greek New Testament, s. 202. 
celu nie jest możliwe. Bóg i Jego Syn - Logos jest w najwyższym stopniu $\dot{\alpha} \pi \alpha \theta \eta ́$ s. Takim też jest i wcielony Logos i to przez cały czas, a więc od chwili

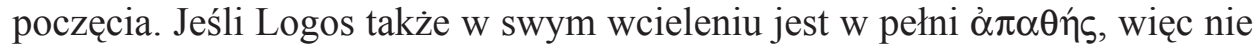
może podlegać żadnej formie bierności. Stąd też dziewicze poczęcie jest dla Klemensa, owszem, prawdą zaczerpniętą z Pisma Świętego, ale trzeba dodać, iż jest to prawda niezwykle odpowiadająca jego soteriologii i ją potwierdzająca. Logos przyjmując ludzkie ciało nie poczyna się jak każdy inny człowiek. Każdy bowiem może powtórzyć za psalmistą: „w grzechu zostałem spłodzony i w bezprawiu poczęła mnie matka moja" ${ }^{38}$. Akt płciowy bowiem ze swej natury wiąże się z biernością i towarzyszącą mu przyjemnością, a to drzwi otwarte dla namiętności, zaś uleganie namiętności jest dla Klemensa istotą grzechu. Zresztą począwszy od grzechu pierwszych rodziców każdy człowiek, poczynający się w sposób naturalny, pozostaje niejako w cieniu grzechu. Z wcielającym się Logosem jest inaczej, gdyż nie poczyna się On na skutek aktu płciowego. A Klemens ma bardzo specyficzny stosunek do ludzkiej seksualności. $\mathrm{Z}$ jednej strony uważa ją za dobra, jak zresztą wszystko, co Bóg stworzył, ale $\mathrm{z}$ drugiej widzi w niej tę dziedzinę życia, w której uleganie namiętności jest szczególnie łatwe. $Z$ nią też, jak wspomnieliśmy wcześniej, wiąże pierwszy grzech człowieka. Nie to jednak jest tu dla niego sprawą rozstrzygająca. Najistotniejsze jest co innego, mianowicie owo wspomniane już nieuleganie bierności. Gdyby Logos wcielony począł się w Maryi z relacji z mężczyzną, byłby poczęty na sposób bierny, co wyraża użyta tu strona bierna. Tymczasem, co Klemens zaznacza z całą moca,

„Z chwilą, gdy Logos wystąpił, stał się przyczyną dzieła stworzenia. Następnie sam siebie poczyna, skoro «Logos stał się ciałem»"39.

To bardzo oryginalna interpretacja tekstu prologu Janowego, zmierzająca do udowodnienia, że już w swoim poczęciu Logos nie jest jego przedmiotem, lecz podmiotem, jego ciało nie jest skutkiem czyjegoś działania, lecz to On sam je poczyna.

Jest jeszcze jedna racja, dla której Logos poczyna w Maryi samego siebie, a nie dzieje się to przez kontakt z mężczyzną. Otóż według nauki Klemensa przy ludzkim poczęciu Bóg za każdym razem stwarza rządzący element duszy

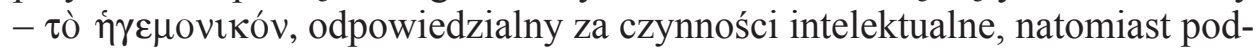

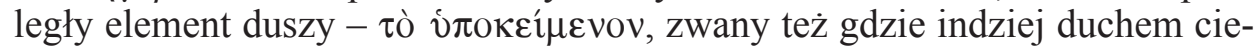
lesnym - $\pi v \varepsilon \hat{v} \mu \alpha \sigma \alpha \rho \kappa \imath \kappa o ́ v$ - odpowiedzialny za ciało i jego czynności, jest przy poczęciu zawarty w nasieniu męskim i przez nie przekazywany. Otóż, to właśnie ów element podległy czyli duch cielesny staje się instancją, przez którą namiętności wchodzą do rządzącej części duszy, opanowując potem całego

${ }^{38}$ Clemens Alexandrinus, Stromata III 100, 7 PG 8, 1201A, thum. Niemirska-Pliszczyńska, I, s. 288, por. Ps 51, 7.

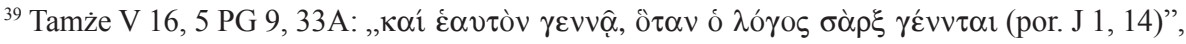
thum. Niemirska-Pliszczyńska, II, s. 17. 
człowieka. Logos wcielony, jako że nie został poczęty przez działanie męskiego nasienia, nie posiada owego elementu podległego i stąd też namiętności nie mogą się do niego dostać. Jego ciałem zaś zamiast elementu podległego rządzi specjalna święta $\operatorname{moc}^{40}$.

Logos nie tylko sam siebie poczyna, ale też i sam siebie rodzi. Tak też należy ostatecznie rozumieć cytowane wcześniej słowa, iż Maryja „urodziła i nie urodziła zarazem". Owszem, z jednej strony Maryja jest jego rodzicielka, ale z drugiej Logos sam siebie urodził, gdyż to On przede wszystkim działał. Klemens zgodziłby się tu w pełni ze słowami konstytucji soborowej Lumen Gentium, iż wcielony Logos rodząc się Maryi „nie naruszył Jej dziewictwa,

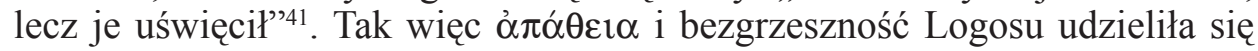
także Jego Matce, przynajmniej w tym, co tegoż macierzyństwa dotyczyło ${ }^{42}$.

W Maryi następuje podniesienie kobiecości do eschatologicznego szczytu. Wprawdzie nie jest to zamiarem Klemensa wprost, ale dzieje się to niejako przy okazji jego soteriologii, w której Maryja zdaje się odgrywać tylko z pozoru rolę narzędzia i tła. Jest to jednak narzędzie i tło przebóstwiane i przez to przestaje być narzędziem i tłem, a jaśnieje boską doskonałością.

$* * *$

Problematyka kobiecości i jej roli w historii zabawienia nie jest w dziełach Klemensa Aleksandryjskiego zagadnieniem centralnym. Jego wizja Boga, człowieka i świata, to wizja progresywnie wcielającego się Logosu Bożego. Zrodzenie Logosu przez Ojca, stworzenie świata i człowieka, objawienie w Starym Testamencie - i na pewien sposób, choć nie bezpośredni w filozofii greckiej - to kolejne etapy swoiście rozumianego wcielania się Logosu ${ }^{43}$. Ostatnim etapem tego wcielania się jest wcielenie w Jezusie Chrystusie. Kobiecość u Klemensa widzieć trzeba na tym wielkim tle o wymiarach kosmicznych. Człowiek dla niego to od początku mężczyzna i kobieta, którzy są sobie zasadniczo - czyli na poziomie dusz - równi. Różni ich ciało i te różnice nie tylko wyznaczają ich biologiczne i społeczne role, ale też i pozycje, gdyż słabsze i mniej doskonałe - zdaniem Klemensa - ciało kobiety bardziej obciąża jej duszę niż to jest w przypadku mężczyzny. Stąd też mężczyzna jest w drodze do zbawienia głowa, a nawet panem kobiety. Nie jest to jednak stan absolutny. Jeśli kobieta idzie drogą zbawienia, a mężczyzna nie, to głową kobiety jest Pan. Te różnice wynikające $\mathrm{z}$ ciała znoszą się jednak w eschatologii. Tam jest już pełna równość. $W$ tej drodze do spełnienia eschatologicznego

${ }^{40}$ Por. Łucarz, Grób czy światynia, s. 35, 91-95 i 241.

${ }^{41}$ Concilium Vaticanum II: Constitutio „Lumen gentium” 57, thum. pol.: Sobór Watykański II, Konstytucje, Deklaracje, Dekrety, Poznań 2002, Pallottinum, 157.

${ }^{42}$ Por. Th. Rüther, Die Lehre von der Erbsünde bei Clemens von Alexandrien, Freiburg 1922, Herder, 47.

${ }^{43}$ Por. Łucarz, Grób czy świqutynia, s. 253-254. 
fundamentalną rolę pełni wcielony Logos, a On wciela się i przychodzi na świat poprzez kobietę. Wybiera to, co słabsze, aby ukazać swą moc. W ten sposób to kobieta, a nie mężczyzna, doznaje jako pierwsza Jego przebóstwiającej bliskości i działania.

\section{WOMAN AND HER ROLE IN THE HISTORY OF SALVATION ACCORDING TO CLEMENT OF ALEXANDRIA}

\section{(Summary)}

The article focuses on the notion of femaleness and its role in the history of salvation in the works of Clement of Alexandria. Although these are not the central themes of his considerations, he reflects on this subject against the background of his magnificent vision of the incarnation of the divine Logos. The begetting or generating of Logos by Father is the first stage of the incarnation, which is followed by the next stages: the creation of the world and of human beings, the revelation in the Old Testament and - although not directly - in the Greek philosophy. The last stage is the incarnation in Jesus Christ. All this leads towards the divinization and the unity in God. Femaleness in Clement's work should be considered as a part of cosmic dimensions. For him, men and women are substantially - i.e. on the level of their souls - equal, hence in the spiritual and intellectual dimension both sexes are vested with identical dignity and enjoy equal rights. The differences between sexes are located in the body and affect various aspects of human life, mostly biological and reproductive ones, not to mention the family, community and religious reality. In practice, it is the woman who is subordinated to man due to the fact, as Clement holds, that the female body is weaker than the male one, more subjugated to passivity, less perfect and more susceptible to passions. For that reason, on the way to salvation, it is the man who is the head of the woman. However, it is not an absolute subjection. If the woman goes on the way to salvation (a Christian woman), and the man does not, the Lord is the head of the woman (the divine Logos, whom she follows). All these differences resulting from the possession of a body are eliminated in eschatology, in which will be the total equality. On that way to the eschatological fulfillment, the divine Logos is indispensable. He incarnates himself and comes to the world through a woman. He chooses what is weaker in order to reveal His power. This way it is a woman, and not a man, who first experiences His divinizing closeness and action.

Key words: Clement of Alexandria, woman, man, salvation, divinization.

Słowa kluczowe: Klemens Aleksandryjski, kobieta, mężczyzna, zbawienie, przebóstwienie. 


\section{BIBLIOGRAFIA}

\section{Źródła}

Clemens Alexandrinus, Protrepticus, PG 8, 49-246, thum. J Sołowianiuk: Klemens Aleksandryjski, Zachęta Greków, w: Apologie, PSP 44, Warszawa 1988, ATK, 99- 201.

Clemens Alexandrinus, Paedagogus, PG 8, 247-684, tłum. M. Szarmach: Klemens Aleksandryjski, Wychowawca, Toruń 2012, Wydawnictwo Naukowe Uniwersytetu Mikotaja Kopernika.

Clemens Alexandrinus, Stromata, PG 8, 685 - 9, 602, thum. J. Niemirska-Pliszczyńska: Klemens Aleksandryjski, Kobierce zapisków filozoficznych dotyczqcych prawdziwej wiedzy, I-II, Warszawa 1994, Instytut Wydawniczy Pax, Akademia Teologii Katolickiej.

Concilium Vaticanum II: Constitutio „Lumen gentium”, tłum. pol. Sobór Watykański II, Konstytucje, Deklaracje, Dekrety, Poznań 2002, Pallottinum, 97-166.

Novum Testamentum graece, ed. K. Aland - M. Black - C.M. Martini - B.M. Metzger A. Wikgren: The Greek New Testament, New York - London - Edinburgh - Amsterdam - Stuttgart $1975^{3}$, United Bible Societies.

\section{Opracowania}

Evdokimov P., Kobieta i zbawienie świata, thum. E. Wolicka, Poznań 1991, Wydawnictwo Polskiej Prowincji Dominikanów „W Drodze”.

Kopaliński W., Encyklopedia ,,drugiej ptci”, Warszawa 1995, Oficyna Wydawnicza RYTM.

ŁucArz S., Grób czy światynia. Problematyka cielesności w antropologii Klemensa Aleksandryjskiego, Kraków 2007 , WAM.

RÜTHER TH., Die Lehre von der Erbsünde bei Clemens von Alexandrien, Freiburger Theologische Studien 28, Freiburg 1922. 